\title{
Treatment of Tissue Paper Wastewater: Application of Electro-Fenton Method
}

\author{
Umran Tezcan Un, Seher Topal, Emre Oduncu, and Ulker Bakir Ogutveren
}

\begin{abstract}
The Fenton process is one of the most powerful advanced electrochemical processes based on the production of hydroxyl radicals $(\mathrm{OH})$ as a result of the reaction of hydrogen peroxide $\left(\mathrm{H}_{2} \mathrm{O}_{2}\right)$ with catalyst ferrous ions $\left(\mathrm{Fe}^{2+}\right)$ under acidic conditions. In this study, tissue paper wastewater with the initial COD concentration of $1200 \mathrm{mg} / \mathrm{L}$ was treated using Electro-Fenton method. The cylindrical iron electrochemical reactor was used as a cathode. The turbine impeller with 8 flat blades were used as an anode. The effects of initial $\mathrm{pH}$, current density and concentration of $\mathrm{H}_{2} \mathrm{O}_{2}$ on COD removal efficiency were determined. The removal efficiency of $80 \%$ were obtained after 60 minutes of electro-fenton process at the current density of $20 \mathrm{~mA} / \mathrm{cm}^{2}$ with the addition of $0.1 \mathrm{M} \mathrm{H}_{2} \mathrm{O}_{2}$. Additionally, the electrical energy consumptions were also evaluated. It can be concluded from the study that reactor designed dissimilar from those in the literature, can be used successfully for COD removal from the tissue paper industry wastewater.
\end{abstract}

Index Terms-Tissue paper wastewater, electro-fenton, wastewater treatment, COD.

\section{INTRODUCTION}

High consumption of freshwater is one of the most important environmental concerns in the paper industries [1]. Effluents of the pulp and paper industry contain a number of toxic compounds and may cause deleterious environmental impacts upon direct discharge to receiving waters [2].

The pulp and paper industry is the sixth largest polluter discharging a variety of gaseous, liquid and solid wastes into the environment [3]. The most significant sources of pollution in paper and paper industry are wood preparation, papering, paper washing, bleaching and coating operations. Papering processes utilize large amounts of water, which reappear in the form of an effluent [4]. This kind of paper mill wastewater, containing many toxic and intensely colored, mainly organic substances, is characterized by a high level of chemical oxygen demand (COD) [5].

Traditional methods for dealing with the wastewater consist of biological, physical, and chemical processes and various combinations of these [6]. The most of the pulp and paper mills treat their effluents by using biological treatment systems. The effluent from the biological treatment still contains significant amount of color compounds, microorganisms, recalcitrant organic compounds and suspended solids. Also, chemical oxygen demand (COD) cannot be removed effectively by biological treatment. Hence, advanced treatment is necessary to improve wastewater discharge quality and to reuse wastewater as

Manuscript received May 7, 2014; revised August 11, 2014.

Ulker Bakir Ogutveren is with the Anadolu University, Turkey (e-mail: uogutver@anadolu.edu.tr). process water [1].

The method of electrochemical oxidation for treatment of the organic contaminants contained in wastewater has become a hot focus in recent years because of its convenience and effectiveness than traditional methods [5].

The Fenton process is one of the most powerful advanced electrochemical processes. Its oxidation mechanism is based on the production of hydroxyl radicals $\left(\mathrm{OH}^{*}\right)$ as a result of the reaction of hydrogen peroxide $\left(\mathrm{H}_{2} \mathrm{O}_{2}\right)$ with catalyst ferrous ions $\left(\mathrm{Fe}^{2+}\right)$ under acidic conditions, as shown as equation (1).

$$
\mathrm{Fe}^{2+}+\mathrm{H}_{2} \mathrm{O}_{2} \rightarrow \mathrm{Fe}^{3+}+\mathrm{OH}^{-}+\mathrm{OH}
$$

$\mathrm{Fe}^{3+}$ produced can react with $\mathrm{H}_{2} \mathrm{O}_{2}$ and hydroperoxyl radical in the so-called Fenton-like reaction, which leads to regenerating $\mathrm{Fe}^{2+}$ (reactions (2) and (3)). $\mathrm{Fe}^{2+}$ regeneration is also possible by reacting with organic radical intermediates (reaction (4)) [7].

$$
\begin{gathered}
\mathrm{Fe}^{3+}+\mathrm{H}_{2} \mathrm{O}_{2} \rightarrow \mathrm{Fe}^{2+}++\mathrm{HO}_{2}+\mathrm{H}^{+} \\
\mathrm{Fe}^{3+}+\mathrm{HO}_{2} \rightarrow \mathrm{Fe}^{2}++\mathrm{O}_{2}+\mathrm{H}^{+} \\
\mathrm{Fe}^{3+}+\mathrm{R} \rightarrow \mathrm{Fe}^{2}++\mathrm{R}^{+}
\end{gathered}
$$

The purpose of the work was to investigate the performance of the reactor designed differently from those in the literature to obtain direct dischargeable effluent from the paper mill wastewater. The effects of operation parameters are initial $\mathrm{pH}$, current density and concentration of $\mathrm{H}_{2} \mathrm{O}_{2}$ are examine. Energy consumption was also analyzed.

\section{EXPERIMENTAL STUDIES}

\section{A. Wastewater}

In the experimental studies, tissue paper industry wastewater obtained from Kocaeli/Turkey. The wastewater taken from paper industry not only has specific odor but also has a specific color, between yellow and green. The wastewater has $1200 \mathrm{mg} / \mathrm{L} \mathrm{COD}$, and $\mathrm{pH}$ of 7 . The wastewater was stored at refrigerator.

\section{B. Experimental Setup and EC Apparatus}

The electrochemical system consisted of a reactor, a mechanical stirrer, and a direct current (DC) power supply (Statron 2257); its schematic representation and picture were shown in Fig. 1. A cylindrical iron reactor operated as anode has an internal diameter of $8.2 \mathrm{~cm}$ and height of $10 \mathrm{~cm}$. Anode has 8 pedal blade with a dimensions of $1.8 \mathrm{~cm} \times 3 \mathrm{~cm}$ while acting as mechanical stirrer. It submerged into the reactor 
containing wastewater and maintained uniform composition by stirring the mixture at $100 \mathrm{rpm}$. The performance of the reactor was evaluated in the batch mode.

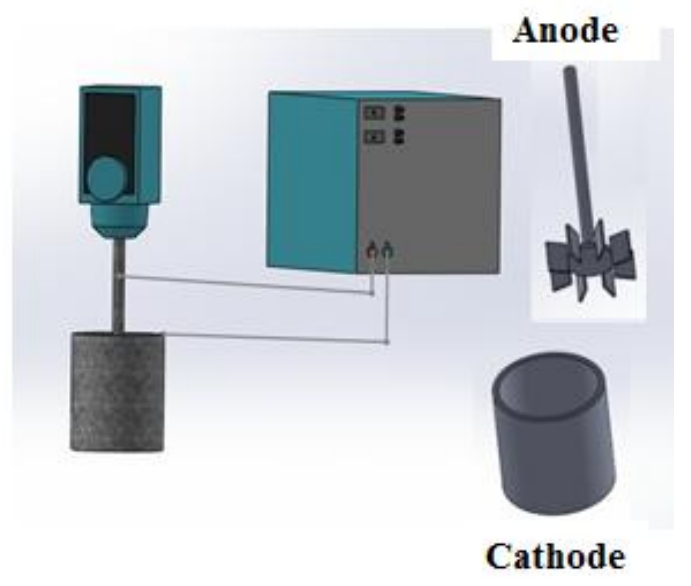

Fig. 1. The experimental set-up and anode and cathode.

\section{Experimental Procedure}

In each run, $0.5 \mathrm{~L}$ of model solution was poured into the electrolytic cell, and the $\mathrm{pH}$, conductivity, and current density were adjusted to the desired value. The mechanical stirrer was submerged into the reactor. Constant agitation speed rate at $100 \mathrm{rpm}$ was selected to enable the agglomeration of flocs in the solution. The reaction was started by switching the DC power supply on. Electrocoagulation experiments were performed for $60 \mathrm{~min}$ for each run and samples were taken every 15 min interval, filtered and analyzed to determine COD concentrations using Close-Reflux Methods. All the samples were analyzed in duplicate to ensure data reproducibility, and an additional measurement was carried out, if necessary.

The effects of initial $\mathrm{pH}$, current density and the concentration of $\mathrm{H}_{2} \mathrm{O}_{2}$ on removal efficiency and energy consumption was investigated. The removal efficiencies $(\mathrm{RE} \%)$ and energy consumptions $\left(E_{c} ; \mathrm{kWh} / \mathrm{m}^{3}\right)$ were calculated using following equations;

$$
\mathrm{RE} \%=\frac{\left(C_{O}-C\right)}{C_{O}} \times 100
$$

where $C_{o}$ and $C$ are the concentrations of COD before and after $E_{C}$, respectively, in $\mathrm{mg} / \mathrm{L}$.

$$
E_{C}=\frac{V \times I \times t}{v_{W}}
$$

where $V$ is Voltage (V), $I$ is Current (A), $t$ is operation time (h) and $v_{w}$ is the volume of the wastewater $\left(\mathrm{m}^{3}\right)$.

\section{RESULTS AND DISCUSSION}

\section{A. Effect of Initial pH}

$\mathrm{pH}$ has a significant impact in Electro-Fenton process because of controlling the variation of iron $\left(\mathrm{Fe}^{+2}-\mathrm{Fe}^{+3}\right)$ and the oxidation ability of hydroxyl radical generated [8]. The initial $\mathrm{pH}$ of the wastewater was adjusted using $4 \mathrm{~N} \mathrm{H}_{2} \mathrm{SO}_{4}$.
As known, Electro- Fenton process may occur more efficiently in lower $\mathrm{pH}$. Therefore, experiments were run in the acidic range. In all experiments, $\mathrm{pH}$ was not controlled but monitored during operation. As seen from Fig. 2, for the initial $\mathrm{pH}$ of 2, 3 and 4 the removal efficiencies of $76 \%, 76 \%$ and $80 \%$ were obtained respectively after 60 minutes at the current density of $20 \mathrm{~mA} / \mathrm{cm}^{2}$ and addition of $0.1 \mathrm{M} \mathrm{H}_{2} \mathrm{O}_{2}$.

At low $\mathrm{pH}$ the reaction may slow down due to the complex species of iron $\left[\mathrm{Fe}\left(\mathrm{H}_{2} \mathrm{O}\right)_{6}\right]^{2+}$, which reacts slower with peroxide compared to $\left[\mathrm{Fe}(\mathrm{OH})\left(\mathrm{H}_{2} \mathrm{O}_{5}\right)^{2+}\right.$. Additionally, at the high concentration of $\mathrm{H}^{+}$ions, hydrogen peroxide gets solvated and more stable form named oxonium ion $\left[\mathrm{H}_{3} \mathrm{O}_{2}\right]^{+}$ was occurred [9].

As seen from Fig. 3, the energy consumptions were 127, $284,285 \mathrm{kWh} / \mathrm{m}^{3}$, at $\mathrm{pH} 2,3$ and 4 , respectively. The decrease in the $\mathrm{pH}$ of solution may increase conductivity of the solution. Therefore, when the conductivity increases, ability to carry electricity is also increased and low energy needed [10]. Therefore subsequent experiments were performed at $\mathrm{pH} 2$ because of lower energy consumption.

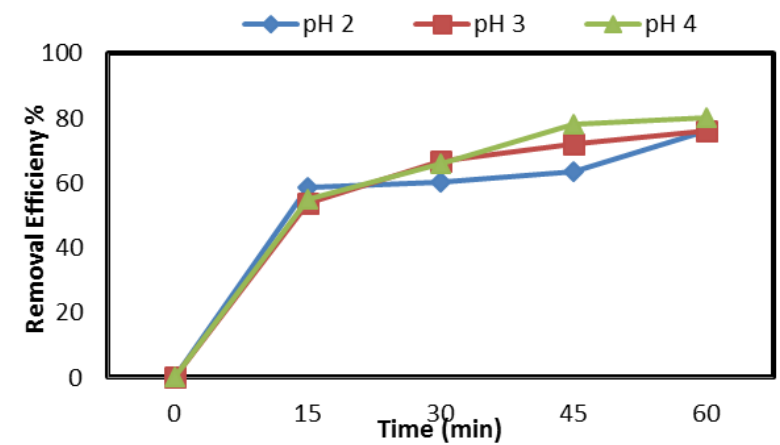

Fig. 2. Effects of initial $\mathrm{pH}$ on COD removal efficiency $\left(i=20 \mathrm{~mA} / \mathrm{cm}^{2}\right.$, $\left.\mathrm{C}_{\mathrm{H}_{2} \mathrm{O}_{2}}=0.1 \mathrm{M}\right)$

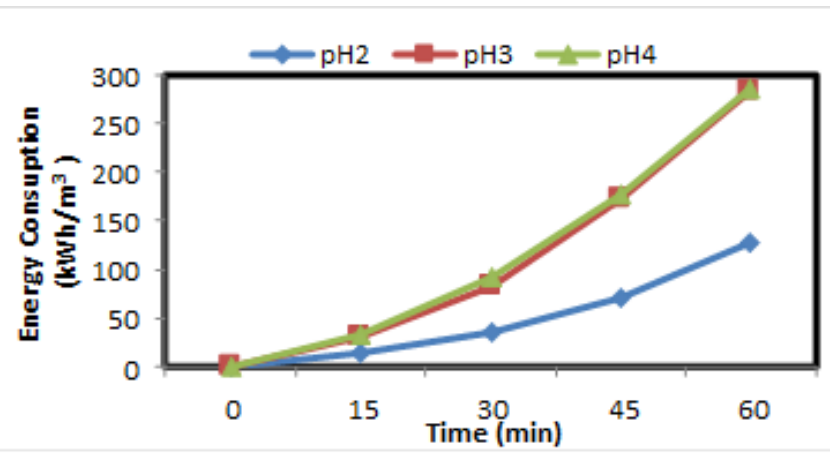

Fig. 3. Effects of initial pH on energy consumption $\left(i=20 \mathrm{~mA} / \mathrm{cm}^{2}, \mathrm{C}_{\mathrm{H}_{2} \mathrm{O}_{2}}=\right.$ $0.1 \mathrm{M})$.

\section{B. Effect of Current Density}

Current density has an important role in the electrochemical processes. According to Faraday's law (Eq. 7 ), the amount of oxidized iron generated from electrode released from anode increases with increasing current (I). Therefore, iron may have more possibility to make complex species to reduce COD.

$$
m=\frac{I \times t \times M}{z \times F}
$$

where $m$ is the mass of generated metal ions (gram); $I$ is the 
current(Ampere), $t$ is the operation time (min, $\mathrm{h}$ ); $M$ is the atomic weight of metal $(\mathrm{g} / \mathrm{mol}), z$ is the number of electrons transferred in the anodic dissolution, and $F$ is Faraday's constant (96 $486 \mathrm{C} / \mathrm{eq}$ ).

As seen from the results in the Fig. 4, removal efficiencies were $74 \%, 75 \%, 76 \%$ and $78 \%$, at the current densities of 10 , $15,20,25 \mathrm{~mA} / \mathrm{cm}^{2}$, respectively.

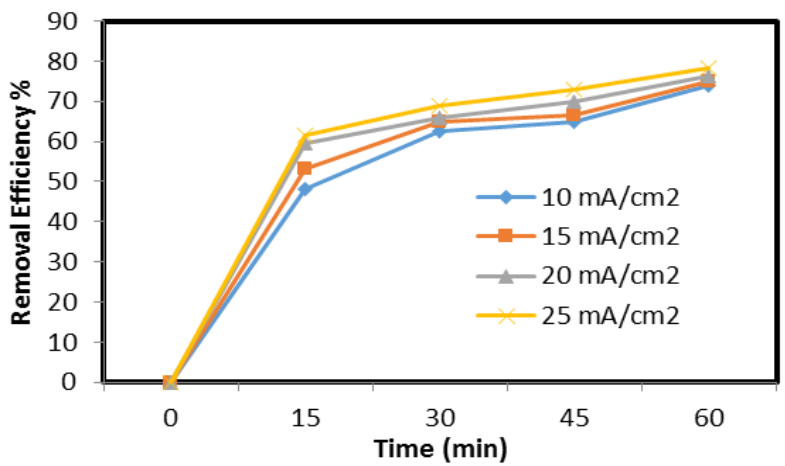

Fig. 4. Effects of current density on COD removal efficiency $\left(\mathrm{pH} 2, \mathrm{C}_{\mathrm{H}_{2} \mathrm{O}_{2}}=\right.$ $0.1 \mathrm{M})$

Energy consumption depends on current that applied. Increasing current results with increasing energy consumption. As seen from the Fig. 5, energy consumptions of $5,28,48,58 \mathrm{kWh} / \mathrm{m}^{3}$ were obtained at current densities of $10,15,20,25 \mathrm{~mA} / \mathrm{cm}^{2}$, respectively.

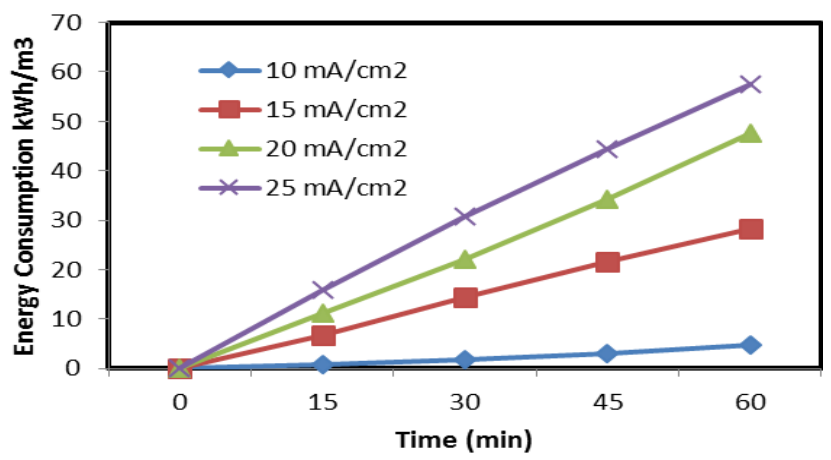

Fig. 5. Variation of energy consumption with time for different current densities $\left(\mathrm{pH} 2, \mathrm{C}_{\mathrm{H}_{2} \mathrm{O}_{2}}=0.1 \mathrm{M}\right)$.

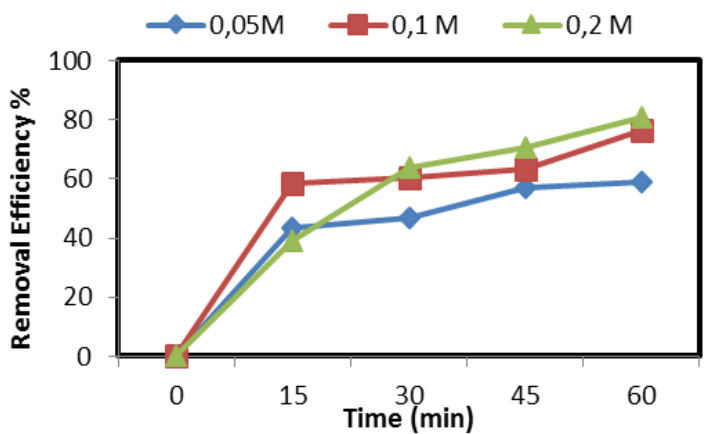

Fig. 6. Effects of $\mathrm{H}_{2} \mathrm{O}_{2}$ concentration on COD removal efficiency (pH 2 , $i=$ $\left.20 \mathrm{~mA} / \mathrm{cm}^{2}\right)$.

\section{Effect of Concentration of $\mathrm{H}_{2} \mathrm{O}_{2}$}

Dosage of $\mathrm{H}_{2} \mathrm{O}_{2}$ is also important parameter for COD removal in the Electro-Fenton process. With increasing dosage of $\mathrm{H}_{2} \mathrm{O}_{2}$ the hydroxyl radicals which is important for complex formations are also increased. The removal efficiencies of $60 \%, 76 \%$ and $81 \%$ were obtained at $0.05,0.1$, $0.2 \mathrm{M}$ of $\mathrm{H}_{2} \mathrm{O}_{2}$, respectively. As it can be easily seen from the results in the Fig. 6 that, COD removal was increased with increasing dosage of $\mathrm{H}_{2} \mathrm{O}_{2}$.

It is also observed that, after 60 minutes Electro-Fenton process, energy consumptions of 126,123 , and $96 \mathrm{kWh} / \mathrm{m}^{3}$ were consumed at the presence of $0.05,0.1$ and $0.2 \mathrm{M}$ of $\mathrm{H}_{2} \mathrm{O}_{2}$ respectively (Fig. 7).

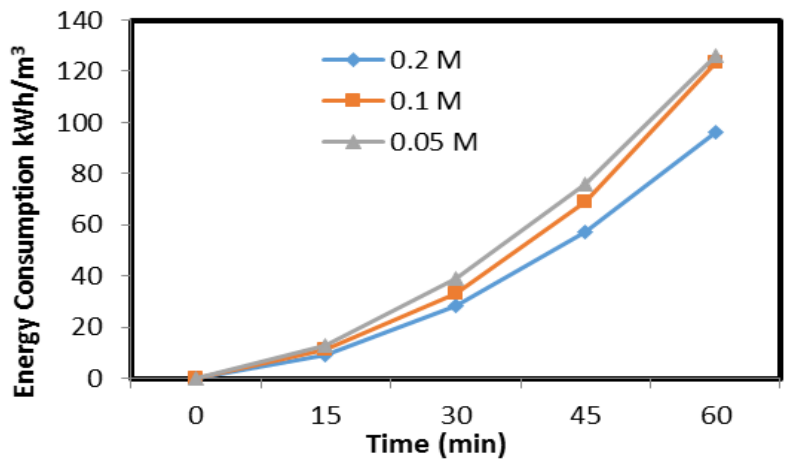

Fig. 7. Variation of energy consumption with time for different $\mathrm{H}_{2} \mathrm{O}_{2}$ concentration $\left(\mathrm{pH} 2, i=20 \mathrm{~mA} / \mathrm{cm}^{2}\right)$.

\section{CONCLUSION}

In this study the performances of Electro-Fenton process on COD removal from the paper mill wastewater were investigated. Based on the results achieved from the experiments, the following conclusions may be outlined:

1) Electro-Fenton with iron electrode could be applicable for COD removal from the tissue paper wastewater.

2) The removal efficiencies increased by increasing the current density. However, increasing the current density caused the energy consumption to increase.

3) The initial COD of $1200 \mathrm{mg} / \mathrm{L}$ was reduced to $228 \mathrm{mg} / \mathrm{L}$

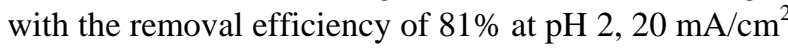
and addition of $0.2 \mathrm{M} \mathrm{H}_{2} \mathrm{O}_{2}$.

It can be concluded from the study that iron reactor and anode with 8 paddle blade, designed dissimilar from those in the literature, can be used successfully for COD removal from the paper industry.

\section{ACKNOWLEDGEMENT}

This study was supported by Anadolu University Scientific Research Projects Commision under grant no: 1101F006 Turkey.

\section{REFERENCES}

[1] B. Z. Gonder, S. Arayici, and H. Barlas, "Advanced treatment of pulp and paper mill wastewater by nanofiltration process: Effects of operating conditions on membrane fouling," Separation and Purification Technology, vol. 76, pp. 292-302, 2011.

[2] M. Y. Ghaly, T. S. Jamil, I. E. El-Seesy, E. R. Souaya, and R. A. Nasr, "Treatment of highly polluted paper mill wastewater by solar photocatalytic oxidation with synthesized nano $\mathrm{TiO}_{2}$," Chemical Engineering Journal, vol. 168, pp. 446-454, 2011.

[3] M. Ugurlu, A. Gurses, C. Dogar, and M. Yalcin, "The removal of lignin and phenol from paper mill effluents by Electrocoagulation," Journal of Environmental Management, vol. 87, pp. 420-428, 2008.

[4] T. Kamil, M. Ghaluy, I. El-Seesy, E. Souaya, and R. Nasr, "A comparative study among different photochemical oxidation processes to enhance the biodegradability of paper mill wastewater," Journal of Hazardous Materials, vol. 185, pp. 353-358, 2011. 
[5] B. Wang, W. Kong, and H. Ma, "Electrochemical treatment of paper mill wastewater using three-dimensional electrodes with $\mathrm{Ti} / \mathrm{Co} / \mathrm{SnO}_{2}-\mathrm{Sb}_{2} \mathrm{O}_{5}$ anode," Journal of Hazardous Materials, vol. 146 , pp. 295-301, 2007.

[6] A. Gurses, S. Karaca, C. Dogar, R. Bayrak, M. Akyıldız, and M. Yalcın, "Determination of adsorptive properties of clay/water system: methylene blue sorption," Journal of Colloid and Interface Science, vol. 269, pp. 310-314, 2009.

[7] N. S. S. Mart'ınez, J. F. Fernández, X. F. Segura, and A. S. Ferrer, "Pre-oxidation of an extremely polluted industrial wastewater by the Fenton's reagent," Journal of Hazardous Materials, vol. B101, pp. 315-322, 2003

[8] S. Sahinkaya, "COD and color removal from synthetic textile wastewater by ultrasound asisted electro-fenton oxidation process," Journal of Industrial and Engineering Chemistry, vol. 19, pp. 601-605, 2013.

[9] A. Babuponnusami and K. Muthukumar, "Advanced oxidation of phenol: A comparison between Fenton, electro-Fenton, sono-electro-Fenton and photo-electro-Fenton processes," Chemical Engineering Journal, vol. 183, pp. 1-9, 2012.

[10] A. E. Yilmaz, R. Boncukcuoglu, and M. M. Kocakerim, "An empirical model for parameters affecting energy consumption in boron removal from boron-containing wastewaters by electrocoagulation," J. Hazard. Mater., vol. 144, pp. 101-107, June 2007.

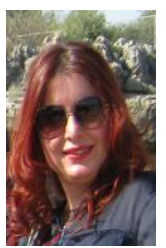

Umran Tezcan Un was born on July 13, 1971 in Eskisehir, Turkey. She graduated from the Department of Chemical Engineering, Anadolu University in 1992 and achieved to study environmental engineering at Anadolu University.

She is currently an associate professor at Anadolu University, Department of Environmental Engineering. She has 22 years of teaching and research experience in the field of environmental science and technology. Her research spans are industrial pollution control, water treatment and electrochemical treatment methods. She has directed and supervised numerous research studies and projects in the field of wastewater management and industrial pollution control. She has got married and is the mother of a girl and a son.

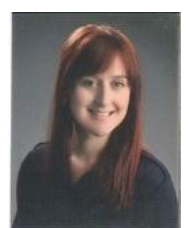

Seher Topal was born in Bilecik, Turkey and graduated from Anatolian High School in 2004. She received her undergraduate degree in envrionmental engineering from the Faculty of Engineering at Anadolu University in 2010. She is studying her M.A. degree in environmental engineering about advanced treatment especially electrocoagülation. Since 2013 she has been working as a trademark \& pattern attorney in Turkey.

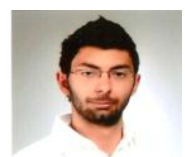

Emre Oduncu was born on March 11, 1989 in Istanbul Turkey. He graduated from the Department of Biology and Department of Chemistry at the same time, Eskisehir Osmangazi University, Turkey in 2011. Now he has two bachelor degrees in chemistry and biology.

$\mathrm{He}$ is a master student in the Department of Environmental Engineering at Anadolu University / Turkey. His research spans are electrochemical treatment methods, wastewater treatment

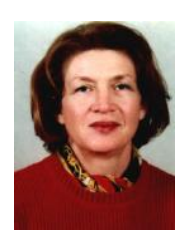

Ulker Bakir Ogutveren graduated from Gazi University, Department of Chemical Engineering in 1972. She achieved the professor degree in 1998, in the Department of Environmental Engineering.

She is currently a professor at Anadolu University, Department of Environmental Engineering. She dedicated her life to teaching in the field of environmental science and technology. Her research spans are industrial water pollution control, water pollution control and electrochemical applications. She has directed and supervised numerous research studies and projects in the field of wastewater management and industrial pollution control. She has a blissful marriage. 